Tetiana Vasylieva,

D.Sc., Professor, Sumy State University, Ukraine

(iD) ORCID ID, 0000-0003-0635-7978

email: tavasilyeva@fem.sumdu.edu.ua

Olha Kuzmenko,

D.Sc., Professor, Sumy State University, Ukraine

(iD) ORCID ID, 0000-0001-8575-5725

email: o.kuzmenko@uabs.sumdu.edu.ua

Musayeva Naila Rashid,

Ph.D., Azerbaijan Tourism and Management University, Azerbaijan

iD ORCID ID, 0000-0001-8760-1500

email: naila_musayeva@yahoo.com

Sergej Vojtovic,

D.Sc., Associated Professor, Alexander Dubcek University of Trencin, Slovakia

(iD) ORCID ID, 0000-0001-7704-3875

email: sergej.vojtovic@tnuni.sk

Maria Kascha,

Sumy State University, Ukraine

(iD) ORCID ID, 0000-0001-9055-8304

email:m.kascha@uabs.sumdu.edu.ua

Hlib Lieonov,

Technical University of Hamburg, Germany

(i) ORCID ID, 0000-0002-7104-9253

email: hliblieonov@icloud.com

Correspondence author: m.kascha@uabs.sumdu.edu.ua

\title{
INNOVATIONS IN GOVERNMENT MANAGEMENT OF THE HEALTHCARE SYSTEM: FORECASTING OF COVID-19 CONSEQUENCES IN SOCIAL, INVESTMENT AND BUSINESS DEVELOPMENT
}

Abstract. This paper summarizes the arguments and counterarguments within the scientific discussion on the issue of the need for an innovative policy in the area of health protection at the link with the transformation of the social and economic development of the country through the pandemic COVID-19. The main goal of this study is to predict two scenarios for the development of the main indicators of the country's socio-economic development: considering the pandemic COVID-19 and the possible course of events without the influence of epidemiological threats. The systematization of literary sources and approaches to innovation and the determination of the volume of negative consequences for the national economy, due to the introduction of quarantine restrictions, has shown that this issue is quite relevant around the world. The study of the transformation of the trajectory of economic development of Ukraine in the article was carried out in the following logical sequence: 1) collection of statistical information, including 118 indicators of social development, the state of capital investment and business expectations of Ukrainian enterprises and screening of multicollinear indicators among them; 2) performing a time series decomposition separately for the interval 5 years before quarantine and taking into account the impact of the pandemic; 3) forecasting the consequences of the pandemic according to the investigated indicators of economic development in 2020-2022 by turning the time series into the Fourier series. The methodological tools of the study were methods of checking for multicollinearity by Pearson coefficients, decomposition of additive models into trend and cyclic components, selection of cyclic oscillations by fast Fourier transform, extrapolation of constructed models for subsequent years and quality

Cite as: Vasylieva, T., Kuzmenko, O., Rashid, M. N., Vojtovic, S., Kascha, M., \& Lieonov, H. (2020). Innovations in government management of the healthcare system: forecasting of covid-19 consequences in social, investment and business development. Marketing and Management of Innovations, 4, 11-25. http://doi.org/10.21272/mmi.2020.4-01 
T., Vasylieva, O., Kuzmenko, S., M. N., Rashid, Vojtovic, M., Kascha, V., Lieonov. Innovations in government management of the healthcare system: forecasting of covid-19 consequences in social, investment and business development

control of constructed models by F-test quarterly data for 2015-2020 are selected. The study empirically confirms and theoretically proves that among the socio-economic development factors studied, most experienced significant transformations due to the introduction of quarantine restrictions by the government. This leads to the need for innovation policy in the health sector in order to minimize such consequences in the future.

Keywords: Fourier series, forecasting, COVID-19, innovation, time series decomposition, health care.

Introduction. The COVID-19 pandemic has led to a slowdown in economic development around the world, reduced cross-border capital movements, increased government borrowing, as well as an increase in the number of unemployed around the world and increased inequality in income distribution among different segments of the population. Today, the world economy is in a state of turbulence due to the possible introduction of long-term and short-term lockdowns by governments, as well as uncertainty about the duration of the pandemic and the timing of its completion. A year has passed since the virus became known to the world and the most important problem is the speed of its spread, which is why no national health system in the world was ready to serve such an influx of patients. Thus, new hospitals were built in some countries (Wuhan, China), some of them converted shopping centers (Tehran, Iran), stadiums (Sao Paulo, Brazil). Ukraine is a country with an intensive rate of coronavirus disease, with an increase in the number of confirmed cases per COVID-19 per day by 2.2 times compared to previous months. During the year, the Cabinet of Ministers of Ukraine, together with relevant departments, introduced a set of temporary regulatory restrictions to prevent crisis events in the real and financial sectors of the economy, and at the same time redistribute financial resources in favor of the health system. In the context of the pandemic, there is an unequivocal need to improve the protection of the population from COVID-19, and innovation in the national health system is the main source of this protection. Under these conditions, there is an objective need to study the nature and strength of transformational changes in the socio-economic development of Ukraine in connection with the pandemic.

Literature Review. The reflection of the relevance of this study is confirmed by many scientific papers on the introduction of innovation in the health system and the consequences of the pandemic in socioeconomic development. Particular attention is focused on innovations in the health system in connection with COVID-19, the authors reflect on those innovations that are likely to remain after the pandemic medicine online, advances in virtual diagnostics, etc. (Woolliscroft, 2020). Heinonen and Strandvik (2020) analyzed key service innovations that emerged at the onset of the pandemic. COVID-19-related changes in innovation management are being investigated (George et al., 2020; Abi Younes et al., 2020). Mallinson (2020) note the need for convergent innovation during the pandemic-induced economic crisis. In a study by Yarovenko et al. (2020) noted the need for innovation in order to implement an effective state policy in the field of information security. Leonov et al. (2017) emphasize the need for innovation in the field of entrepreneurship. Samoilikova (2020) analyzed the impact of the level of the country's innovation development index on the well-being of the population. The questions of motivation of employees as an instrument of innovation within one enterprise in the work of Tovmasyan and Minasyan (2020) are considered. Delanoy and Kasztelnik (2020) investigate innovative management tools to improve employee productivity. Goncharenko (2020) focuses on the importance of innovative banking policies Al Halbusi and Tehseen (2018) consider the Word-Of-Mouth method as a tool to strengthen the level of trust among the population, that is, to generate a positive response in any area - it is the key to building a loyal attitude of people in the service sector. In Umadia and Kasztelnik (2020) conducted a detailed analysis of innovative business strategies that can be tested for the healthcare sectorln addition, the possibility of improving the control system through blockchain technology was considered (Lopez and Alcaide, 2020). Gupta (2019) analyzed the advantages and disadvantages of using various models, thanks to which it is possible to implement investment projects in various sectors of the economy. Thus, innovations, regardless of the scope of their application, make it possible to increase the effectiveness of management decisions and quickly respond to outrage of the external and internal environment, and therefore a large number of ideas 
can be used for the health sector, to minimize negative impacts that can be caused by epidemiological consequences. Sufficient attention has also been paid to the capacity of public policies to direct their influence over certain areas of society to achieve sustainable development, which has become even more relevant in view of the consequences of the pandemic. COVID-19 The authors Vasylieva et al. (2017) proved that public investment in education is the key to the socio-economic development of the country. In the work of Ibragimov et al. (2019) considers the relationship between investing in ecology and indicators of stable development. Scientists Toyin and Oludayol (2020) searched for factors that affect the country's economic growth. In a study by Bilan et al. (2019a) proved the truth of the hypothesis that the volume of capital investment affects the rate of economic growth. Kuzmenko et al. (2018) built a generalizing indicator of the effectiveness of the functioning of executive authorities, which can be adapted for the health system. The work analyzed the state of debt security of the state to the pandemic (Sirenko et al., 2020). In conditions of uncertainty, it is important to secure the value of financial assets through the implementation of a balanced investment policy (Vasilyeva et al., 2019; Oliinyk and Kozmenko, 2019).

Analysing trends in scientific issues, it was revealed that a significant number of studies are devoted to the identification of causal relationships between indicators of socio-economic development and the pandemic. For example, Kuzmenko et al. (2020) investigated the prerequisites of the differential impact of the pandemic on the regions of Ukraine. Dutta et al. (2020) emphasize importance of the report of objective information to society in the conditions of COVID-19 pandemic. The paper (Mallinson, 2020) examines the levers of public policy to regulate the negative effects on the country's economy during the pandemic. Scientists Yelnikova and Kwilinski (2020) have identified the necessary areas of investment policy, which should be aimed at supporting the healthcare system of Ukraine. The scientific work (Probst and Kasztelnik, 2020) emphasizes the need for effective training of medical personnel. Khomenko et al. (2020) emphasize that one of the important criteria for assessing health is the required number of donors to receive enough donor blood. The issues of government innovation, health care reform and overcoming the effects of the pandemic are relevant. Thus, we will assess the impact of quarantine restrictions on the transformation in the socio-economic development of Ukraine and test the hypothesis of increasing crisis processes in various sectors of the national economy. As a research tool, we will use Fourier series analysis (Levchenko et al., 2019) to decompose the time series and identify the cyclic component (Bilan et al., 2019b). The purpose of the article is to determine the level of transformation of socio-economic development of the country to a pandemic and since the introduction of quarantine restrictions.

Methodology and research methods. It is proposed to conduct an in-depth analysis of economic and social indicators within two periods: before the pandemic and since the introduction of quarantine restrictions to determine the structural changes in the development of the national economy.

The first stage. Collection of statistical information (The State Statistics Service of Ukraine, 2020). The following 118 indices were used to conduct a comprehensive analysis of the development of the socioeconomic sphere of Ukraine:

1. Indices of social development (income and expenditure of the population; the amount of average monthly wages; the number of unemployed, employed and economically active population; the need for workers; indicators of natural increase (number of births, deaths, total population); migration rates , number of permanent population).

2. Indices of capital investment (volume of investments in tangible assets by areas of placement (construction of residential buildings, non-residential buildings, engineering structures, vehicles, machinery and equipment, land, long-term assets of crop and livestock), volume of investments in intangible assets by areas of placement: (software collateral, copyrights and patents), the amount of investment by source of funding (state and local budgets, funds of enterprises and foreign investors, funds of the population for individual housing construction), the amount of investment by type of economic 
T., Vasylieva, O., Kuzmenko, S., M. N., Rashid, Vojtovic, M., Kascha, V., Lieonov. Innovations in government management of the healthcare system: forecasting of covid-19 consequences in social, investment and business development

activity (agriculture, forestry and fisheries, construction, industry, transport - water, aviation, land, pipeline, postal, etc.).

3. Indices of wholesale and retail trade (turnover, sales of petroleum products, sales).

4. Indices of business activity of enterprises (level of confidence in services, industry, construction and trade; expected changes in production in the above areas).

The information and statistical base on the above indicators was formed for the period - I quarter of 2015 to II quarter of 2020, which allow to comprehensively assess the level of social and economic development of the country. But the larger the data set, the greater the probability of multicollinearity in the input data, so let's check for a linear functional relationship between the selected indicators.

The second stage. Elimination of indicators that have a very close relationship with each other, using Pearson's pairwise correlation coefficients. To do this, we build a symmetric matrix of correlation coefficients using the MS Excel data analysis package, which will consist of elements $r_{i j}$ (1).

$$
r_{i j}=\frac{\sum_{1}^{118}\left(x_{i}-\bar{x}_{i}\right) \cdot \sum_{1}^{118}\left(x_{j}-\bar{x}_{j}\right)}{\sqrt{\sum_{1}^{118}\left(x_{i}-\bar{x}_{i}\right)^{2} \cdot \sum_{1}^{118}\left(x_{j}-\bar{x}_{j}\right)^{2}}}
$$

where $r_{i j}$-Spearman's linear correlation coefficient, $x_{j}, x_{i}$ - respectively $j$ or $i$ indicator of input data, $\bar{x}_{j}, \bar{x}_{i}$ - the average value of the corresponding time series.

The values of the coefficients obtained by formula (1) can vary in the range from -1 to 1 . The greater the relationship, the closer the absolute value to 1. Given this, we find the value:

$$
\left|r_{i j}\right| \geq 0,7
$$

and remove one of the variables that was used to calculate the corresponding coefficient from the study, preferring that variable that has the smallest number of critical values of paired correlation coefficients paired with other factors.

The third Stage. Decomposition of time series, until the onset of 2020 into seasonal and trend components. To build the most accurate forecast, you must decompose the time series into components (3).

$$
f(t)=V_{t}+S_{t}+\varepsilon_{t}
$$

where $y_{t}$ - series level at time $t, V_{t}$ - trend model, $S_{t}$ - seasonal component, $\varepsilon_{t}$ - random variable.

Considering the data of 2015-2019, in which the appearance will choose the best trend line to decompose for the selected indicators «before COVID-19». Over 4 years, the production of coke and refined products increased by an average of almost UAH 22 million. quarterly, the trend has the form (4):

$$
V_{t}=21,98 t+49,28
$$

where $V_{t}$ - trend component of the additive model, $\mathrm{t}$ - level number of series.

Removing the trend component from formula (3), and calculate the value for each time interval by formula (4) and subtract from the corresponding level of the input series:

$$
f(t)-V_{t}=S_{t}+\varepsilon_{t}
$$


Thus, the result of this stage is the sum of seasonal and random components that must be used to build a forecast. To study the seasonal component, we turn to the Fast Fourier Transform (FFT) method.

The Fourth Stage. Decomposition of a time series into a Fourier series. To apply the FFT method, use the program MathCad.v.15. General view of the Fourier series:

$$
S(t)=\frac{a_{0}}{2}+\sum_{k=1}^{\infty} A_{k} \cos \left(k \frac{2 \pi t}{T}+\theta_{k}\right)
$$

where $S(t)$ - seasonal component, $a_{0}$ - free term, $k$ - harmonic number, $A_{k}$ - amplitude of the oscillation, $\frac{2 \pi t}{T}-$ frequency, $\theta_{k}$ - phase of $k$-fluctuation.

The FFT method is to sequentially divide the input series into two equal parts, so the length of the series can only be a power of two: $2^{n}$. When studying the data from the first quarter of 2015 to the fourth in 2020 , the length 20 , the closest value of the power of two is $2^{4}=16$. Therefore, for further research we will use data only from 2016. According to formula (6) the number of harmonics in the studied series $2^{4-1}+1=9$, which are shown in Table 1 , but considering only 3 , which have the greatest weight and reflect the basic patterns of a number: $U_{1}, U_{4}, U_{8}$.

Table 1. Values of harmonics

\begin{tabular}{lrrrrrrrrr}
\hline $\begin{array}{l}\text { Number of } \\
\text { Harmonica }\end{array}$ & $\mathbf{0}$ & $\mathbf{1}$ & $\mathbf{2}$ & $\mathbf{3}$ & $\mathbf{4}$ & $\mathbf{5}$ & $\mathbf{6}$ & $\mathbf{7}$ & $\mathbf{8}$ \\
\hline Weight & $3,8 \cdot 10^{3}$ & $2,6 \cdot 10^{4}$ & $6,5 \cdot 10^{3}$ & $1,2 \cdot 10^{4}$ & $5,9 \cdot 10^{4}$ & $2,4 \cdot 10^{3}$ & $1 \cdot 10^{3}$ & $4,3 \cdot 10^{3}$ & $9 \cdot 10^{4}$ \\
\hline
\end{tabular}

Source: developed by the authors.

Determining the numbers of influential oscillations, we calculate the values of the corresponding amplitudes (7) and phases (8) - the angle between the number $U$ in a complex form with a positive axis direction. Substituting the obtained values into formula (6) we obtain (9):

$$
\begin{gathered}
A_{k}=\frac{\left|U_{k}\right|}{e} \\
\theta_{k}=\arg \left(U_{k}\right) \\
S(t)=-59,7 \cos \left(\frac{1}{16} \pi t-0,51\right)-89,64 \cos \left(\frac{4}{5} \pi t+1,69\right)-110,35\left(\frac{8}{15} \pi t-3,14\right)
\end{gathered}
$$

where $A_{k}$ - amplitude k- fluctuation, $U_{k}$ - harmonica, $\theta_{k}$ - phase, $S(t)$ - seasonal component.

The fifth stage. Calculation of forecast values. Using formula (9), substituting the following values of $t$, returning the trend to the model.

$$
f(t)=V_{t}+S_{t}+\varepsilon_{t}
$$

The sixth stage. Checking the adequacy of the model using Fisher's test (11):

$$
F=\frac{\sum_{1}^{n}\left(\hat{y}_{t}-\bar{y}\right)^{2}}{m}: \frac{\sum_{1}^{n}\left(f(t)-\hat{y}_{t}\right)^{2}}{n-(m+1)}
$$


where $\mathrm{F}$ - the actual value of the Fisher test, $\hat{y}_{t}$ - empirical values, $\bar{y}$ - the average value of the series, $n$-number of levels, $m=1$ - the number of factors involved in the study, $f(t)$ - theoretical values.

Results. As a result of the second stage (multicollinearity check) we get 18 variables, which are characterized by the lack of linear relationship between them: the number of employed population, the amount of natural and migratory growth; volume of capital investments for commercial designation rights; volume of capital investments at the expense of foreign investors, volume of capital investments at the expense of the population, volume of capital investments for individual housing construction; volume of capital investments in fisheries, volume of capital investments in water transport, volume of capital investments in telecommunications and postal activities; volume of production of oil refining products, volume of production of computers, volume of production of electrical equipment, volume of production of motor transport, volume of production of furniture; change in sales and inventories in trade.

Having determined the type of growth curve for each selected variable, we proceed to the next step the identification of the cyclic component by constructing Fourier series. Putting together formulas (4), (9) and substituting them in formula (10) we obtain:

$$
\begin{gathered}
f(t)=21,98 t+49,28-59,7 \cos \left(\frac{1}{16} \pi t-0,51\right)-89,64 \cos \left(\frac{4}{5} \pi t+1,69\right) \\
-110,35\left(\frac{8}{15} \pi t-3,14\right)
\end{gathered}
$$

The constructed model (12) is a trend-seasonal additive model that takes into account general growth trends and seasonal fluctuations depending on the quarter. Substituting in formula (12) the numbers of the following levels of the series $t=16.27$ we will get the forecast for 2020-2022. Let's analyze the decomposition of the time series taking into account the impact of the COVID-19 pandemic. We continue to study the indicator "production of coke and refined products", but this time we will take the range of dates 1st quarter 2015 - 2nd quarter 2020, check whether there was a shift due to the introduction of quarantine restrictions. Repeating the above methodology from stage III to V. Due to the data entry in 2020, the increase in the function changes significantly from UAH 22 million to UAH 16.5 million. for the quarter, but there is a positive trend. Therefore, we can make preliminary conclusions that the predicted values will change.

$$
V_{t}^{*}=16,45 t+90,4
$$

where $V_{t}^{*}$ - trend component for the data of 2015-2020.

By repeating the following steps to select the seasonal component and decompose it into a Fourier series, we obtain the formula for the seasonal component (14) and the general additive trend-seasonal model (15).

$$
\begin{gathered}
S^{*}{ }_{t}=167,16 \cos (2 \pi t \cdot 0)+117,95 \cos \left(2 \pi t \cdot \frac{4}{16}-1,543\right)+ \\
+79,465 \cos \left(2 \pi t \cdot \frac{8}{30}-3,142\right)
\end{gathered}
$$


T., Vasylieva, O., Kuzmenko, S., M. N., Rashid, Vojtovic, M., Kascha, V., Lieonov. Innovations in government management of the healthcare system: forecasting of covid-19 consequences in social, investment and business development

$$
\begin{gathered}
f(t)^{*}=16,45 t+90,4+167,16 \cos (2 \pi t \cdot 0)+117,95 \cos \left(2 \pi t \cdot \frac{4}{16}--1,543\right) \\
++79,465 \cos \left(2 \pi t \cdot \frac{8}{30}-3,142\right)
\end{gathered}
$$

Substituting in Formula (15) the numbers of the following levels of the series $t=16 . .25$ we obtain the forecast for 2020-2022 (Table 2) and compare the obtained values of the two types of forecast. The values are quite close, so we can conclude that the COVID-19 pandemic has hardly transformed this indicator of the development of the oil refining industry.

Table 2. Comparison of predicted values under the influence of a pandemic and without.

\begin{tabular}{cccccc}
\hline Time & $\begin{array}{c}\mathbf{2 0 1 5 - 2 0 1 9} \\
\text { years }\end{array}$ & $\begin{array}{c}\mathbf{2 0 1 5 - 2 0 2 0} \\
\text { years }\end{array}$ & Time & $\begin{array}{c}\mathbf{2 0 1 5 - 2 0 1 9} \\
\text { years }\end{array}$ & $\begin{array}{c}\mathbf{2 0 1 5 - 2 0 2 0} \\
\text { years }\end{array}$ \\
\hline I 2020 & 485,074 & & III 2021 & 572,186 & 629,44 \\
II 2020 & 290,475 & & IV 2021 & 755,364 & 785,113 \\
III 2020 & 626,203 & 532,229 & I 2022 & 455,581 & 562,92 \\
IV 2020 & 566,13 & 732,761 & II 2022 & 572,774 & 464,692 \\
I 2021 & 501,994 & 525,764 & III 2022 & 772,012 & 719,785 \\
II 2021 & 518,232 & 379,501 & IV 2022 & 590,834 & 826,346 \\
\hline
\end{tabular}

Source: developed by the authors.

For model (12) the value of the Fisher test: $F=22,09$, while the tabular value of the F-test is 4.49. Thus, the actual value far exceeds the critical value - this means that the results of the model are adequate and it is significant. For model (15) the value: $F=36,36$, and the corresponding critical -4.41 . Therefore, the actual value is much higher than the table and the constructed model is significant. Using similar calculations for the next 17 indicators until the introduction of quarantine restrictions, we obtain results that have the form (16) - (32) and are presented in Table 3. The number of employed populations aged 15-70 years (16) is described by the trend as a polynomial function of the second order, which means the existence of both a decline and an increase in the number in the study period. Until 2017, there was a decrease in the number of employed population, excluding the cyclical component, and from 2017 to 2020 a steady increase. The natural decrease of the population (17) has a linear decreasing dependence, ie during the studied period of time the difference between live births and the number of deaths quarterly increased by an average of 1289 people. The level of migration growth of the population of Ukraine (18) has a slight positive trend, ie the difference between arrivals and departures increased by an average of 142 people each year.

$$
\begin{aligned}
& f(t)=4,19 t^{2}-79,42 t+16531+33,34 \cos (2 \pi t+2,38)+133,13 \cos \left(\frac{3}{4} \pi t \cdot+2,94\right)+ \\
& 65,18 \cos (\pi t-3,14) \\
& f(t)=-1289,7 t-41650+3027 \cos \left(\frac{1}{2} \pi t-2,766\right)+13340 \cos \left(\frac{1}{2} \pi t \cdot+3,127\right)+ \\
& +6749 \cos (\pi t) \\
& \quad f(t)=141,55 t+2361,3+2558 \cos \left(\frac{1}{2} \pi t+0,585\right)+666,203 \cos \left(\frac{1}{2} \pi t-0,045\right)+147(\pi t-
\end{aligned}
$$

The dynamics of capital investment in rights to commercial designations, industrial property, copyright and related rights, patents, licenses, concessions (19) during 2015-2017 was stable, while in 2018 there was a significant jump (600\% compared to with the corresponding quarters of previous years). 
T., Vasylieva, O., Kuzmenko, S., M. N., Rashid, Vojtovic, M., Kascha, V., Lieonov. Innovations in government management of the healthcare system: forecasting of covid-19 consequences in social, investment and business development

Table 3. Forecasted indices of socio-economic development of Ukraine before the quarantine restrictions introduction.

\begin{tabular}{|c|c|c|c|c|c|c|c|c|c|}
\hline & $\begin{array}{c}\text { Number of } \\
\text { employed } \\
\text { population } \\
15-70\end{array}$ & $\begin{array}{l}\text { Natural } \\
\text { population } \\
\text { growth }\end{array}$ & $\begin{array}{l}\text { Migratory } \\
\text { growth of } \\
\text { persons }\end{array}$ & $\begin{array}{l}\text { The amount of } \\
\text { capital } \\
\text { investment for } \\
\text { the acquisition } \\
\text { of commercial } \\
\text { rights. } \\
\text { designations, } \\
\text { copyrights and } \\
\text { related rights }\end{array}$ & $\begin{array}{l}\text { The amount } \\
\text { of capital } \\
\text { investments } \\
\text { at the } \\
\text { expense of } \\
\text { foreign } \\
\text { investors }\end{array}$ & $\begin{array}{l}\text { The amount } \\
\text { of capital } \\
\text { investment at } \\
\text { the expense } \\
\text { of the } \\
\text { population for } \\
\text { individual } \\
\text { housing } \\
\text { construction }\end{array}$ & $\begin{array}{c}\text { The } \\
\text { amount of } \\
\text { capital } \\
\text { investment } \\
s \text { in } \\
\text { fisheries }\end{array}$ & $\begin{array}{l}\text { The amount } \\
\text { of capital } \\
\text { investments } \\
\text { in water } \\
\text { transport }\end{array}$ & $\begin{array}{l}\text { The amount of } \\
\text { capital } \\
\text { investment in } \\
\text { postal and } \\
\text { courier } \\
\text { activities }\end{array}$ \\
\hline 12020 & 16111,38 & $-71690,80$ & 5947,26 & 5999,21 & 588,79 & 8410,246 & 5,48 & 18,91 & 32,8 \\
\hline II 2020 & 16405,35 & $-69408,20$ & 4862,09 & 3543,3 & 1153,32 & 6577,114 & 12,70 & 38,26 & 92,18 \\
\hline III 2020 & 16546,01 & $-41961,00$ & 6340,36 & 2571,49 & 228,73 & 7745,54 & 12,18 & 81,55 & 45,91 \\
\hline IV 2020 & 16649,41 & $-73819,00$ & 7910,31 & 2641,54 & $-120,4$ & 9490,917 & 27,19 & 68,88 & 173,33 \\
\hline | 2021 & 16399,04 & $-76849,60$ & 6513,46 & 974,45 & 1042,26 & 8825,933 & 6,32 & 33,05 & 39,52 \\
\hline II 2021 & 16724,08 & $-74567,00$ & 5428,29 & 748,92 & 1602,89 & 7686,421 & 13,54 & 52,53 & 99,84 \\
\hline III 2021 & 16898,23 & $-47119,80$ & 1200,24 & 2555,1 & 580,89 & 8401,645 & 13,03 & 93,28 & 54,65 \\
\hline IV 2021 & 17035,13 & $-78977,80$ & 8476,51 & 2243,23 & 57,48 & 9296,006 & 28,03 & 75,8 & 183,29 \\
\hline | 2022 & 16818,24 & $-82008,40$ & 7079,66 & 1416,49 & 997,22 & 8788,67 & 7,17 & 33,59 & 50,83 \\
\hline II 2022 & 17176,78 & $-79725,80$ & 5994,49 & 2638,78 & 1321,76 & 8554,925 & 14,38 & 46,13 & 112,68 \\
\hline III 2022 & 17384,42 & $-52278,60$ & 1766,44 & 2615,4 & 87,92 & 9427,07 & 13,87 & 80,4 & 69,18 \\
\hline IV 2022 & 17554,82 & $-84136,60$ & 9042,71 & 1710,18 & $-589,51$ & 9470,162 & 28,88 & 57,91 & 199,71 \\
\hline \multirow[t]{2}{*}{ F-test } & 7,74 & 193,89 & 48,2 & 9,19 & 21,5 & 23,97 & 19,29 & 17,11 & 19,1 \\
\hline & $\begin{array}{l}\text { The amount } \\
\text { of capital } \\
\text { investment in } \\
\text { the } \\
\text { production of } \\
\text { refined } \\
\text { products }\end{array}$ & $\begin{array}{l}\text { The amount } \\
\text { of capital } \\
\text { investment in } \\
\text { the } \\
\text { production of } \\
\text { computers } \\
\text { and optical } \\
\text { products }\end{array}$ & $\begin{array}{l}\text { The amount } \\
\text { of capital } \\
\text { investment } \\
\text { in the } \\
\text { production } \\
\text { of electrical } \\
\text { equipment }\end{array}$ & $\begin{array}{l}\text { The amount of } \\
\text { capital } \\
\text { investment in } \\
\text { the production } \\
\text { of cars and } \\
\text { trailers }\end{array}$ & $\begin{array}{l}\text { The amount } \\
\text { of capital } \\
\text { investment } \\
\text { in furniture } \\
\text { production }\end{array}$ & $\begin{array}{l}\text { Change in } \\
\text { sales for the } \\
\text { previous } \\
\text { three months, }\end{array}$ & $\begin{array}{l}\text { Change in } \\
\text { sales for } \\
\text { the } \\
\text { previous } \\
\text { three } \\
\text { months, }\end{array}$ & $\begin{array}{l}\text { Estimation of } \\
\text { the current } \\
\text { volume of } \\
\text { stocks of } \\
\text { goods }\end{array}$ & $\begin{array}{l}\text { The amount of } \\
\text { capital } \\
\text { investment in } \\
\text { telecommunic } \\
\text { ations }\end{array}$ \\
\hline I 2020 & 452,379 & 185,007 & 272,101 & 1274,839 & 581,332 & 9,81 & $-4,936$ & $-4,225$ & 1684,861 \\
\hline II 2020 & 360,913 & 281,613 & 655,904 & 1507,356 & 651,166 & $-3,042$ & 32,74 & $-2,916$ & 4642,182 \\
\hline III 2020 & 549,067 & 185,637 & 295,239 & 1454,022 & 680,752 & 11,886 & 22,78 & $-2,9$ & 1154,436 \\
\hline IV 2020 & 616,361 & 286,839 & 634,51 & 1730,292 & 660,186 & 25,122 & 35,98 & $-1,118$ & 4907,783 \\
\hline | 2021 & 501,994 & 196,836 & 406,702 & 1389,898 & 679,868 & 14,622 & 4,344 & 0,301 & 2029,118 \\
\hline II 2021 & 463,862 & 304,477 & 635,138 & 1658,737 & 749,702 & 7,951 & 42,02 & 0,567 & 5847,807 \\
\hline III 2021 & 664,3 & 220,398 & 543,192 & 1712,011 & 779,288 & 21,449 & 32,06 & 1,637 & 2452,471 \\
\hline IV 2021 & 656,553 & 332,547 & 631,702 & 1754,974 & 758,722 & 30,408 & 45,26 & 0,044 & 5475,134 \\
\hline I 2022 & 527,488 & 250,873 & 598,915 & 1739,068 & 778,404 & 22,649 & 13,624 & 0,961 & 1470,717 \\
\hline II 2022 & 551,098 & 362,958 & 627,918 & 1641,639 & 848,238 & 18,15 & 51,3 & $-0,039$ & 4428,038 \\
\hline III 2022 & 739,317 & 278,761 & 582,004 & 2047,2 & 877,824 & 25,746 & 41,34 & 1,682 & 940,292 \\
\hline IV 2022 & 661,272 & 386,25 & 694,49 & 1805,489 & 857,258 & 30,843 & 54,54 & 2,622 & 4693,639 \\
\hline F-test & 21,52 & 24,36 & 19,42 & 32,68 & 15,93 & 87,87 & 84,06 & 39,19 & 11,46 \\
\hline
\end{tabular}

Source: developed by the authors.

The volume of capital investments from foreign investors $(20)$ is described by an exponential trend: until 2018 there was a rather sharp decline, and then - there was a stabilization of the process. 
T., Vasylieva, O., Kuzmenko, S., M. N., Rashid, Vojtovic, M., Kascha, V., Lieonov. Innovations in government management of the healthcare system: forecasting of covid-19 consequences in social, investment and business development

Its volume is steadily growing quarterly by UAH 104 million. during 2015-2019, and the changes took place only under the influence of the cyclical component regarding to capital investments at the expense of the population for individual housing construction (21).

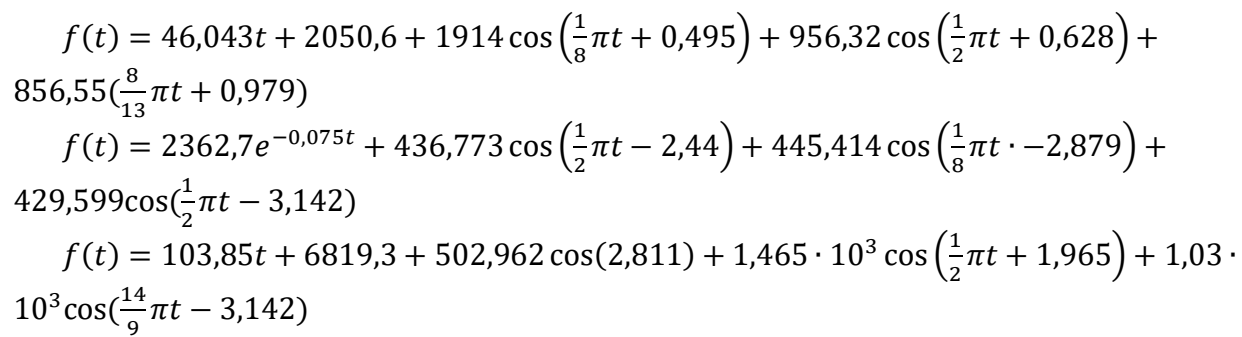

The study of capital investment in fisheries (22) identifies a seasonal component that remains almost unchanged during the study period. Investments in water transport (23) have seasonal fluctuations and a slight negative trend during the study period. Capital investment in postal and courier activities (24) is exponentially dependent due to the difference in growth at the beginning and the end of the study period. Investments in this activity area are increasing every year; the most significant jump took place in 2017. The capital investment volume in telecommunications (25) is quite changeable, and on average, tends to decrease. Capital investments in the production of computers, electronic and optical products (26) have a rather significant tendency to increase from year to year, by an average of UAH 7.13 million per quarter. Capital investments in the electrical equipment production (27) also have positive dynamics to the quarterly growth of UAH 18.25 million. The output of motor vehicles, trailers, semi-trailers and other vehicles (28) has a positive stable trend during the study period. Capital investment in the production of furniture and other products, repair and installation of machinery and equipment (29) in 2015-2019 has a quarterly upward trend, despite sharp fluctuations in volume in 2015

$$
\begin{aligned}
& f(t)=0,2102 t+10,713+4,642 \cos \left(\frac{1}{2} \pi t+1,781\right)+3,308 \cos \left(\frac{1}{2} \pi t+2,287\right)+ \\
& 5,452 \cos (\pi t-3,142) \\
& f(t)=-0,818 t+70,79+18,97 \cos \left(\frac{1}{2} \pi t+2,57\right)+18,97 \cos \left(\frac{1}{2} \pi t+2,5\right)+13,03 \cos \left(\frac{1}{2} \pi t-\right.
\end{aligned}
$$

$$
f(t)=11,779 e^{0,0794 t}+59,187 \cos \left(\pi t \cdot \frac{1}{56}\right)+39,246 \cos \left(\frac{1}{2} \pi t+1,701\right)++45,917 \cos (\pi t-
$$

$$
\begin{aligned}
& f(t)=-26,768 t+4046.2-1278 \cos (\pi t+0,862)-737,906 \cos \left(\frac{1}{4} \pi t-1,26\right)- \\
& -875,51 \cos (\pi t)
\end{aligned}
$$$$
\begin{aligned}
& f(t)=7,1295 t+123,958+21,561 \cos \left(\pi t \cdot \frac{1}{8}+1,777\right)+48,608 \cos (\pi t-3,142) \\
& f(t)=18,253 t+164,45+25,525 \cos \left(\frac{1}{4} \pi t+1,175\right)+90,854 \cos \left(\frac{7}{8} \pi t-3,041\right)+
\end{aligned}
$$$$
+103,843 \cos (\pi t-3,142)
$$$$
f(t)=42,412 t+738,13+96,197 \cos \left(\frac{1}{2} \pi t+2,542\right)+132,68 \cos \left(\frac{7}{8} \pi t-2,106\right)
$$$$
f(t)=24,634 t+286,17+29,16 \cos \left(\frac{1}{2} \pi t+1,785\right)+14,339 \cos \left(\frac{3}{2} \pi t+2,9\right)
$$

Estimation of changes in turnover for the previous three months $(30)$ and the expected changes in sales of goods in the next three months (31) have pronounced seasonal fluctuations, but during 2015- 
T., Vasylieva, O., Kuzmenko, S., M. N., Rashid, Vojtovic, M., Kascha, V., Lieonov. Innovations in government management of the healthcare system: forecasting of covid-19 consequences in social, investment and business development

2019 there was a steady increase in both indices by an average of $1 \%$ quarterly, as and an estimate of the current stock of goods (32) by $0.5 \%$.

$$
\begin{aligned}
& f(t)=1,07 t-5,05+3,14 \cos \left(\frac{1}{8} \pi t \cdot+2,92\right)+10,3 \cos \left(\frac{1}{2} \pi t+1,09\right)+6,03 \cos \left(\frac{16}{11} \pi t\right) \\
& f(t)=2,32 t-18,96+11,559 \cos \left(\frac{1}{2} \pi t-3,081\right)+11,559(\pi t-3,142) \\
& f(t)=0,49 t-10,55+1,22 \cos \left(\frac{1}{4} \pi t-2,381\right)+0,654 \cos \left(\frac{7}{8} \pi t-2,887\right)
\end{aligned}
$$

Table 3 shows the F-test values for each index, calculated by the formula (11), which is greater than the critical value of 4.49 . Thus, all models adequately describe empirical values. We will repeat calculations for 2015-2020, considering data from the moment of the quarantine introduction. We obtain the results presented via additive trend-seasonal models (33)-(49) and forecasted values for each index, shown in table 4.

The number of the employed population (33) in Ukraine until 2020 regularly tended to increase, but in the second quarter of 2020 decreased by $3 \%$ compared to the same period last year. The natural increase (34) had a negative dynamic, and under the influence of the pandemic, decreased by another $51 \%$. Migratory population growth (35) has hardly changed due to the introduction of quarantine restrictions.

$$
\begin{aligned}
& f(t)=1,936 t^{2}-38,95 t+16409+195,265 \cos \left(\frac{2}{5} \pi t+1,934\right)+62,07 \cos \left(\frac{4}{11} \pi t+\right. \\
&+2,488)+83,055 \cos \left(\frac{8}{13} \pi t-0,414\right) \\
& f(t)=-2318,4 t+66236+13500 \cos \left(\frac{8}{15} \pi t-0,469\right) \\
& f(t)=101,85 t+2671,9+3107 \cos \left(\frac{8}{11} \pi t-2,424\right)+1358 \cos \left(\frac{5}{7} \pi t-0,673\right)+ \\
&+1531 \cos \left(\frac{16}{15} \pi t-3,142\right)
\end{aligned}
$$

The amount of capital investment in the purchase of commercial rights, industrial property, copyright and related rights, patents, licenses, concessions (36) has hardly changed, but the beginning of the pandemic has significantly reversed the upward trend. The amount of funds from foreign investors (37) to finance capital investment did not change the general trend, but only offset the possible positive changes within the economic crisis around the world. The amount of allocated funds of the population for individual housing construction (38) decreased by $37 \%$ compared to the same period last year.

$$
\begin{aligned}
& f(t)=3,9823 t+2366+1513 \cos \left(\frac{2}{7} \pi t+3,075\right)+978,006 \cos \left(\frac{5}{6} \pi t+0,616\right)+ \\
& +906,768 \cos (\pi t-2,464) \\
& f(t)=-92,978 t+1431,81+315,616 \cos \left(\frac{1}{7} \pi t+0,246\right)+326,134 \cos \left(\frac{2}{3} \pi t--1,388\right)(37) \\
& f(t)=20,7 t+7443,2+652,103 \cos \left(\frac{1}{5} \pi t-2,46\right)+1131 \cos \left(\frac{8}{15} \pi t-1,054\right)+ \\
& 612,804 \cos \left(\frac{16}{17} \pi t-3,142\right)
\end{aligned}
$$

Capital investment in fisheries (39), water transport (40) and postal and courier activities (41) did not change at all compared to the same quarter of the previous year, but the trend changed only with seasonality. The cost of acquiring non-current assets for telecommunications (42) has increased, and for the production of computers (43) and electrical equipment (44) has decreased due to the introduction of quarantine measures. Investment in the production of motor vehicles, trailers, semi-trailers and other 
T., Vasylieva, O., Kuzmenko, S., M. N., Rashid, Vojtovic, M., Kascha, V., Lieonov. Innovations in government management of the healthcare system: forecasting of covid-19 consequences in social, investment and business development

vehicles (45) decreased by $45 \%$, and in the production of furniture, other products, repair and installation of machinery and equipment (46) by $29 \%$, compared to the previous year.

$$
\begin{aligned}
& f(t)=0,0324 t+12,036+3,537 \cos \left(\frac{1}{7} \pi t \cdot-3,047\right)+3,773 \cos \left(\frac{5}{8} \pi t+2,468\right)+ \\
& +5,035 \cos (\pi t-3,142) \\
& f(t)=-0,8737 t+71,079+11,398 \cos \left(\frac{1}{2} \pi t-0,442\right)+9,612 \cos \left(\frac{5}{9} \pi t-2,776\right)+ \\
& +10,301 \cos (\pi t-3,142) \\
& f(t)=14,263 e^{0,0535 t}+50+59,241 \cos \left(\pi t \cdot \frac{1}{16}\right)+51,927 \cos \left(\frac{1}{2} \pi t-2,2\right)+ \\
& +40,839 \cos (\pi t-3,142) \\
& f(t)=-41,77 t+4158,1-698,378 \cos \left(\frac{1}{4} \pi t-2,753\right)+683,08 \cos \left(\frac{1}{4} \pi t \cdot+1,139\right)+ \\
& 1049 \cos (\pi t-3,142) \\
& f(t)=3,5542 t+177,13+43,354 \cos (\pi t-2,474)+25,56\left(\frac{3}{4} \pi t \cdot+0,825\right) \\
& f(t)=9,9812 t+351,22+60,928 \cos \left(\frac{3}{4} \pi t-2,765\right)+62,339 \cos \left(\frac{5}{8} \pi t+0,175\right) \\
& f(t)=20,964 t+1062,49+226,13 \cos \left(\frac{1}{8} \pi t-2,75\right)+198,977 \cos \left(\frac{1}{2} \pi t-2,06\right) \\
& f(t)=13,09 t+425,79++55,19 \cos \left(\frac{1}{8} \pi t \cdot-2,87\right)+87,33 \cos \left(\frac{1}{2} \pi t-0,63\right)
\end{aligned}
$$

The change in sales of goods for the previous three months (47) or the next three months (48) was transformed the most, compared to previous indices. They had a positive growth trend during 2015-2019, and under the influence of the pandemic, decreased to the level of 2015. The assessment of the current stock of goods (49) also reduced twice, to the level of 2016.

$$
\begin{gathered}
f(t)=0,1887 t+7,38+5,55 \cos \left(\frac{1}{8} \pi t-2,463\right)+12,821 \cos \left(\frac{1}{2} \pi t-0,581\right) \\
f(t)=1,0623 t-0,64+10,46 \cos \left(\frac{1}{8} \pi t-2,712\right)+11,259 \cos \left(\frac{1}{2} \pi t+1,146\right) \\
f(t)=-0,054 t^{2}+1,602 t-11,92+2,93 \cos \left(\frac{1}{8} \pi t-1,62\right)+1,79 \cos \left(\frac{6}{17} \pi t-1\right)
\end{gathered}
$$

Table 4 shows the F-test values for each index, which are greater than their critical value of 4.41 . Therefore, these models are adequate and the obtained results of the forecasts presented in Tables 3 and 4 indicate that measures followed by a significant transformation of socio-economic life of society.

Based on empirical data and theoretical studies, the authors prove that the pandemic has caused a differentiated transformation of life. Quarantine restrictions have significantly affected the labor market state; namely, there has been a significant reduction in staff or transfer to part of the working day. And even if there are no epidemiological crises soon, it will be impossible to increase the number of employed people without the government's influence. Natural population growth has changed significantly for the worse, which is a logical consequence of the pandemic because COVID-19 has caused 13,000 deaths since the beginning of the country's epidemic (The National Health Service of Ukraine, 2020). There were almost no changes in population growth dynamics caused by the temporary closure of borders. In general, the changing trend has not worsened. As for the vector of transformation of capital investments by industries, it is projected that on average the amount of capital investments in water transport will decrease by $17 \%$, in fisheries - by $16 \%$, in postal and courier activities - by $39 \%$, production of vehicles and trailers by $8 \%$, production of electrical equipment $-2 \%$, production of coke and petroleum products - will not change, in telecommunications $-4 \%$, production of furniture, repair and installation of machinery and equipment $-18 \%$, production of computers, electronic and optical products $-12 \%$, the amount of funds for individual housing construction - decreased by $11 \%$. 
T., Vasylieva, O., Kuzmenko, S., M. N., Rashid, Vojtovic, M., Kascha, V., Lieonov. Innovations in government management of the healthcare system: forecasting of covid-19 consequences in social, investment and business development

Table 4. Forecasted values in terms of quarantine

\begin{tabular}{|c|c|c|c|c|c|c|c|c|c|}
\hline & $\begin{array}{l}\text { Number } \\
\text { employed } \\
\text { population } \\
15-70\end{array}$ & $\begin{array}{l}{ }^{\text {of }} \text { Natural } \\
\text { population } \\
\text { growth }\end{array}$ & $\begin{array}{l}\text { Migratory } \\
\text { growth } \\
\text { persons }\end{array}$ & $\begin{array}{l}\text { The amoun } \\
\text { of capita } \\
\text { investment } \\
\text { for the } \\
\text { acquisition o } \\
\text { of commercial } \\
\text { rights. } \\
\text { designations, } \\
\text { copyrights } \\
\text { and relatec } \\
\text { rights }\end{array}$ & $\begin{array}{l}\text { The amou } \\
\text { of capit } \\
\text { finvestments } \\
\text { at th } \\
\text { expense } \\
\text { foreign } \\
\text { investors }\end{array}$ & $\begin{array}{l}\text { The amoun } \\
\text { unt of capita } \\
\text { ital investment a } \\
s \text { the expens } \\
\text { the of } \\
\text { of population fo } \\
\text { individual } \\
\text { housing } \\
\text { construction }\end{array}$ & $\begin{array}{l}\text { Int } \\
\text { tal } \\
\text { at The amoun } \\
\text { se of capita } \\
\text { he of investments } \\
\text { for in fisheries } \\
\text { in }\end{array}$ & $\begin{array}{l}\text { The } \\
\text { nt amount o } \\
\text { al capital } \\
\text { investment } \\
\mathrm{s} \text { in wate } \\
\text { transport }\end{array}$ & $\begin{array}{l}\text { The } \\
\text { of amount of } \\
\text { capital } \\
\text { investment } \\
\text { in postal } \\
\text { in and courier } \\
\text { activities }\end{array}$ \\
\hline III 2020 & 16117,19 & $-73960,6$ & 1906,767 & 2051,281 & 323,024 & 9635,427 & 2,636 & 57,049 & $-47,07$ \\
\hline IV 2020 & 16235,72 & $-94136,6$ & 5214,523 & 4865,375 & $-463,007$ & 6378,2 & 16,118 & 59,89 & 110,14 \\
\hline | 2021 & 16386,47 & $-85489,2$ & 6825,08 & 2336,816 & $-325,557$ & 7230,697 & 12,443 & 34,821 & 22,35 \\
\hline || 2021 & 16572,42 & $-72242,6$ & $-80,59$ & 4556,03 & $-337,628$ & 7541,099 & 18,319 & 77,638 & 39,01 \\
\hline III 2021 & 16466,59 & $-88780,7$ & 9154,244 & $-11,822$ & $-1044,27$ & 8348,495 & 8,613 & 54,387 & $-21,71$ \\
\hline IV 2021 & 16197,91 & -103691 & 3263,989 & 2211,498 & $-767,554$ & 6056,021 & 24,898 & 30,969 & 143,78 \\
\hline | 2022 & 16364,78 & $-89157,6$ & 2732,737 & 636,957 & $-608,061$ & 7963,935 & 10,32 & 64,2 & 63,33 \\
\hline || 2022 & 16728,86 & $-82406,7$ & 9312,367 & 2993,047 & $-1144,825$ & 9175,973 & 16,447 & 59,669 & 86,12 \\
\hline III 2022 & 16710,59 & -103473 & 1630,621 & 3869,832 & $-733,557$ & 8867,855 & 11,185 & 43,317 & 30,11 \\
\hline IV 2022 & 16575,71 & -110942 & 5707,944 & 3602 & $-501,494$ & 7375,172 & 17,818 & 35,409 & 198,71 \\
\hline \multirow[t]{2}{*}{ F-test } & 8,34 & 28,38 & 10 & 12,7 & 32,65 & 22,39 & 26,32 & 27,73 & 17,07 \\
\hline & \multicolumn{2}{|c|}{$\begin{array}{l}\text { The amount } \text { The amount }_{\text {of capital }} \\
\text { of capital } \\
\text { investment investment in } \\
\text { the } \\
\text { production of }{ }_{\text {production of }}^{\text {computers }} \\
\text { refined and optical } \\
\text { products and }\end{array}$} & $\begin{array}{l}\text { The amou } \\
\text { of capit } \\
\text { investment } \\
\text { f the } \\
\text { production } \\
\text { electrical } \\
\text { equipment }\end{array}$ & $\begin{array}{l}\text { unt The amoun } \\
\text { ital of capita } \\
\text { in investment ir } \\
\text { the } \\
\text { of production o } \\
\text { cars and } \\
\text { trailers }\end{array}$ & $\begin{array}{l}\text { IThe amou } \\
\text { nof capit } \\
\text { investment } \\
\text { f furniture } \\
\text { d production }\end{array}$ & $\begin{array}{l}\text { unt } \\
\text { ital Change } \\
\text { in sales for th } \\
\text { previous } \\
\text { months, }\end{array}$ & $\begin{array}{l}\text { in Change ir } \\
\text { he sales in the } \\
3 \text { next } \\
\text { months, }\end{array}$ & $\begin{array}{l}\text { Estimation } \\
\text { in of the } \\
\text { le current } \\
\text { 3volume o } \\
\text { stocks o } \\
\text { goods }\end{array}$ & $\begin{array}{l}\text { The } \\
\text { amount of } \\
\text { capital } \\
\text { of investment } \\
\text { of } \\
\text { telecommu } \\
\text { nications }\end{array}$ \\
\hline 2020 & 2080,342 & 532,229 & & & 16 & 612,891 & $-19,00$ & 2 & -9 , \\
\hline IV 2020 & 3990,569 & 732,761 & 246,058 & 543,39 & 1434,516 & 490,051 & 16,796 & 11,487 & $-1,224$ \\
\hline | 2021 & 2001,462 & 525,764 & 225,834 & 472,845 & 1446,97 & 516,181 & 14,966 & 0,042 & 1,606 \\
\hline || 2021 & 4416,765 & 379,501 & 277,694 & 577,613 & 1285,244 & 652,848 & $-0,533$ & 10,197 & 3,109 \\
\hline III 2021 & 2634,138 & 629,44 & 196,824 & 596,751 & 1474,611 & 655,96 & 5,493 & 30,188 & 2,228 \\
\hline IV 2021 & 4836,371 & 785,113 & 311,355 & 452,459 & 1838,166 & 563,484 & 25,355 & 29,603 & 0,138 \\
\hline | 2022 & 2545,938 & 562,92 & 202,501 & 644,397 & 1826,291 & 616,767 & 23,251 & 19,074 & $-1,151$ \\
\hline || 2022 & 4243,095 & 464,692 & 293,935 & 618,574 & 1595,253 & 773,242 & 6,332 & 27,895 & $-1,063$ \\
\hline III 2022 & 1746,182 & 719,785 & 245,728 & 472,826 & 1680,879 & 785,803 & 10,008 & 44,504 & $-1,07$ \\
\hline IV 2022 & 3656,409 & 826,346 & 274,492 & 690,279 & 1922,056 & 690,977 & 26,946 & 39,005 & $-2,972$ \\
\hline F-test & 14,34 & 36,36 & 21,82 & 18,38 & 29,36 & 17,71 & 16,72 & 20,06 & 7,9 \\
\hline
\end{tabular}

Source: developed by the authors.

Thus, not all areas of the study underwent significant changes: the production of refined products, electrical equipment and telecommunications have hardly changed in capital investment. In contrast, postal and courier activities have suffered, despite a growing population of people switching to online technology, possibly due to increased interstate borders. The index of the investment amount in «rights to commercial designations, copyrights, and related rights, etc.», on the contrary, it increases on average, due to the transition mainly to remote work, which does not interfere with the type of work, with the use of mental activity.

Conclusion. Thus, specific indices of socio-economic development in Ukraine have been transformed because of the introduction of quarantine restrictions caused by COVID-19 pandemic. The business sector has undergone the most significant changes due to the uncertainty of the government's actions and the lack of real business support - the level of expectations among entrepreneurs has dropped critically. The amount of foreign investment has decreased significantly, indicating government programs' direction to support the weaknesses of the economy. Based on empirical data and theoretical research, it was proved that the pandemic had caused a differentiated transformation of different spheres of society. It enables to prioritize industries in the importance of innovation to mitigate the pandemic effects. Health care had most 
T., Vasylieva, O., Kuzmenko, S., M. N., Rashid, Vojtovic, M., Kascha, V., Lieonov. Innovations in government management of the healthcare system: forecasting of covid-19 consequences in social, investment and business development

significant burden on society in 2020. The medical reform launched in 2016 is slowly implemented, due to the lack of authorities' single view in this direction.

Author Contributions: The following statements should be used conceptualization, T. V., O. K; methodology, O. K., M. K., K. D.; validation, T. V., O. K.; formal analysis, O. K., investigation, O. K., M. K.; resources, M. K., H. L.; data curation, O. K, T. V., K. D.; writingoriginal draft preparation, O. K, T. V., M. K; writing-review and editing, S. V., T. V., M. K.; visualization, M. K. H. L.; supervision, O. K., T. V., S. V. All authors have read and approved the final manuscript.

Funding; This study was prepared within the project implementation, registration number 2020.01/0181 «Economic and mathematical modeling and forecasting of the COVID-19 impact on the development of Ukraine in national and regional contexts: public health factors and socio-ecological and economic determinants», implemented by financial support of the National Research Fund of Ukraine

This work was supported by the Slovak Research and Development Agency under the contract No. APVV-19-0579

\section{References}

Abi Younes, G., Ayoubi, C., Ballester, O., Cristelli, G., de Rassenfosse, G., Foray, D., ... \& Zhou, L. (2020). COVID-19: Insights from innovation economists. Science and Public Policy. [CrossRef] [Google Scholar]

Al Halbusi, H.,\& Tehseen, S. (2018). The Effect of Electronic Word-Of-Mouth (EWOM) On Brand Image and Purchase Intention: A Conceptual Paper. SocioEconomic Challenges, 3(2), 83-94. [CrossRef] [Google Scholar]

Bilan, Y., Vasylieva, T., Lyeonov, S., \& Tiutiunyk, I. (2019b). Shadow economy and its impact on demand at the investment market of the country. Entrepreneurial Business and Economics Review, 7(2), 27-43. [CrossRef] [Google Scholar]

Bilan, Y., Brychko, M., Buriak, A., \& Vasilyeva, T. (2019a). Financial, business and trust cycles: the issues of synchronization. Zbornik radova Ekonomskog fakulteta u Rijeci: časopis za ekonomsku teoriju i praksu. Proceedings of Rijeka Faculty of Economics. Journal of Economics and Business, 37(1), 113-138. [CrossRef] [Google Scholar]

Delanoy, N.,\& Kasztelnik, K. (2020). Business Open Big Data Analytics to Support Innovative Leadership Decision in Canada. Business Ethics and Leadership, 4(2), 56-74. [CrossRef] [Google Scholar]

Dutta, P., Dutta, U., Hasan, S., Sarkar, S., \& Sana, T. (2020). Educate, Empower And Protect People Through Timely Authentic Information: Explore How Bangladeshi Newspapers Response To COVID-19 Pandemic. SocioEconomic Challenges, 4(3), 93-103. [CrossRef] [Google Scholar]

George, G., Lakhani, K. R., \& Puranam, P. (2020). What has changed? The Impact of Covid Pandemic on the Technology and Innovation Management Research Agenda. Journal of Management Studies, 57(8), 1754-1758. [CrossRef] [Google Scholar]

Goncharenko, T. (2020). From Business Modelling to the Leadership and Innovation in Business: Bibliometric Analysis (Banking as a Case). Business Ethics and Leadership, 4(1), 113-125. [CrossRef] [Google Scholar]

Gupta, K. (2019). Asset Pricing Models and Stock Selection Ability of the Indian Mutual Fund Managers: An Empirical Study of Open-ended Growth Equity Schemes. Financial Markets, Institutions and Risks, 3(3), 49-62. [CrossRef] [Google Scholar]

Haber, N. (2020). Review 1: «Preprinting a pandemic: the role of preprints in the COVID-19 pandemic». Rapid Reviews COVID19. [CrossRef]

Heinonen, K., \& Strandvik, T. (2020). Reframing service innovation: COVID-19 as a catalyst for imposed service innovation. Journal of Service Management. [CrossRef] [Google Scholar]

Ibragimov, Z., Lyeonov, S. \& Pimonenko, T. (2019). Green investing for SDGS: EU experience for developing countries. Economic and Social Development: Book of Proceedings, 37th International Scientific Conference on Economic and Social Development «Socio Economic Problems of Sustainable Development», 868-877. [Google Scholar]

Khomenko, L., Saher, L., \& Polcyn, J. (2020). Analysis Of The Marketing Activities In The Blood Service: Bibliometric Analysis. Health Economics and Management Review, 1, 20-36. [CrossRef] [Google Scholar]

Kotenko, N. V., Serdiuk, S. G., \& Saltykova, A. V. (2015). Marketing management tools of funding and promotion services of non-governmental organizations. Marketing and Management of Innovations, 4, 20-33. [Google Scholar]

Kuzmenko, O. V., \& Koibichuk, V. V. (2018). Econometric modeling of the influence of relevant indicators of gender policy on the efficiency of a banking system. Cybernetics and Systems Analysis, 54(5), 687-695. [CrossRef] [Google Scholar]

Kuzmenko, O., Lieonov, S., \& Kashcha, M. (2020). Financial, economic, environmental and social determinants for Ukrainian regions differentiation by the vulnerability level to COVID-19. Financial and credit activity: problems of theory and practice, 3 (34), 270-282. [CrossRef]

Lee, S. M., \& Trimi, S. (2020). Convergence innovation in the digital age and in the COVID-19 pandemic crisis. Journal of Business Research, 123, 14-22. [CrossRef]. [Google Scholar] 
T., Vasylieva, O., Kuzmenko, S., M. N., Rashid, Vojtovic, M., Kascha, V., Lieonov. Innovations in government management of the healthcare system: forecasting of covid-19 consequences in social, investment and business development

Leonov, S. V., Vasilyeva, T. A., \& Shvindina, H. O. (2017). Methodological approach to design the organizational development evaluation system. Scientific bulletin of Polissia, 2-3(11), 51-56. [CrossRef] [Google Scholar]

Levchenko, V., Boyko, A., Bozhenko, V., \& Mynenko, S. (2019). Money laundering risk in developing and transitive economies: analysis of cyclic component of time series. Business: Theory and Practice, 20, 492-508. [CrossRef] [Google Scholar]

Lopez, B. S., \& Alcaide, A. V. (2020). Blockchain, Al and loT to Improve Governance, Financial Management and Control of Crisis: Case Study COVID-19. SocioEconomic Challenges, 4(2), 78-89. [CrossRef]. [Google Scholar]

Mallinson, D. J. (2020). Cooperation and Conflict in State and Local Innovation During COVID-19. The American Review of Public Administration, 50(6-7), 543-550. [CrossRef] [Google Scholar]

Marcel, D. T. A. (2019). Impact of the Foreign Direct Investment on Economic growth on the Re-public of Benin. Financial Markets, Institutions and Risks, 3(2), 69-78. [CrossRef] [Google Scholar]

Oliinyk, V., \& Kozmenko, O. (2019). Optimization of investment portfolio management. Serbian Journal of Management, 14(2) 373-387. [CrossRef] [Google Scholar]

Probst, D. T., \& Kasztelnik, K. (2020). The Observational Research Study with the Trends in Healthcare Training and Leadership Ethics in The United States. Business Ethics and Leadership, 4(3), 6-24. [CrossRef] [Google Scholar]

Samoilikova, A. (2020). Financial Policy of Innovation Development Providing: The Impact Formalization. Financial Markets, Institutions and Risks, 4(2), 5-15. [CrossRef]. [Google Scholar]

Sirenko, N., Poltorak, A., Melnik, O., Lutsenko, A., \& Borysenko, L. (2020). Innovative approaches for the evaluation and forecasting of debt levels of the security in Ukraine. Financial And Credit Activity: Problems Of Theory And Practice, 3(34), 207-218. [CrossRef] [Google Scholar]

The National Health Service of Ukraine [Link]

The State Statistics Service of Ukraine. (2020). [Link]

Tovmasyan, G. \& Minasyan, D. (2020). The Impact of Motivation on Work Efficiency for Both Employers and Employees also During COVID-19 Pandemic: Case Study from Armenia. Business Ethics and Leadership, 4(3), 25-35. [CrossRef] [Google Scholar] Toyin, O. W., \& Oludayol, A. E. (2020). Dynamic Effects of Foreign Portfolio Investment on Economic Growth in Nigeria. Financial Markets, Institutions and Risks, 4(3), 5-12. [CrossRef] [Google Scholar]

Umadia Sr, K., \& Kasztelnik, K. (2020). The Financial Innovative Business Strategies of Small to Medium Scale Enterprises in Developing Country and Influence for the Global Economy Performance. SocioEconomic Challenges, 4(3), 20-32. [CrossRef] [Google Scholar]

Vasilyeva, T., Kuzmenko, O., Bozhenko, V., \& Kolotilina, O. (2019). Assessing the dynamics of bifurcation transformations in the economy. SHS Web of Conferences, 65, 04006. [CrossRef] [Google Scholar]

Vasylieva, T. A., Lieonov, S. V., Petrushenko, Y. M., \& Vorontsova, A. S. (2017). Investments in the system of lifelong education as an effective factor of socio-economic development. Financial and credit activity: problems of theory and practice, 2(23), 426-436. [CrossRef] [Google Scholar]

Woolliscroft, J. O. (2020). Innovation in Response to the COVID-19 Pandemic Crisis. Academic medicine : journal of the Association of American Medical Colleges, 95(8), 1140-1142. [CrossRef] [Google Scholar]

Yarovenko, H. (2020). Research of relationship between information security and country development factors. $\Lambda^{\prime} \mathrm{O} О \Sigma, 37-38$. [CrossRefl [Google Scholar]

Yarovenko, H., Kuzmenko, O., \& Stumpo, M. (2020). Strategy for Determining Country Ranking by Level of Cybersecurity. Financial Markets, Institutions and Risks, 4(3), 124-137. [CrossRef] [Google Scholar]

Yelnikova, J.,\& Kwilinski, A. (2020). Impact-Investing in The Healthcare in Terms of the New Socially Responsible State Investment Policy. Business Ethics and Leadership, 4(3), 57-64. [CrossRef] [Google Scholar]

Тетяна Васильєва, д.е.н., профессор, Сумський державний університет, Україна

Ольга Кузьменко, д. е. н., профресор, Сумський державний університет, Україна

Мусєва Наіля Рашид, Ph.D., Азербайджанський Університет Туризму і Менеджменту, Азербайджан

Сергій Войтович, д. е. н., дочент, Університет ім. Олександра Дубчека, Словаччина

Марія Каща, Сумський державний університет, Україна

Гліб Лєонов, Технічний університет Гамбурга, Німеччина

Інновації в державному управлінні системою охорони здоров'я: прогнозування наслідків COVID-19 на соціальний, інвестиційний та підприємницький розвиток в країні

Ця стаття узагальнює аргументи та контраргументи в межах наукової дискусії з питання необхідності проведення інноваційної політики урядом у сфері охорони здоров'я у зв'язку з трансформацією траєкторії соціальноекономічного розвитку країни через пандемію COVID-19. Основною метою даного дослідження є прогнозування двох сценаріїв розвитку основних показників соціально-економічного розвитку країни: з урахуванням пандемії COVID-19 та можливий перебіг подій без впливу епідеміологічних загроз. Систематизація літературних джерел та підходів щодо проведення інноваційної діяльності та визначення обсягу негативних наслідків для національної економіки, через введення карантинних обмежень засвідчила, що це питання є досить актуальним по всьому світі. Дослідження питання транссоормації траєкторії економічного розвитку України в статті здійснено в наступній логічній послідовності: 1) збір статистичної інформації, що включає 118 індикаторів соціального розвитку, стану капітального інвестування та 
T., Vasylieva, O., Kuzmenko, S., M. N., Rashid, Vojtovic, M., Kascha, V., Lieonov. Innovations in government management of the healthcare system: forecasting of covid-19 consequences in social, investment and business development

ділових очікувань підприємств України та відсіювання мультиколінеарних показників серед них; 2) проведення декомпозиції часових рядів окремо для проміжку за 5 років до карантину та з урахуванням впливу пандемії; 3) прогнозування наслідків пандемії по досліджуваним індикаторам економічного розвитку у 2020-2022 роках за допомогою перетворення часового ряду в ряд Фурєє. Методичним інструментарієм проведеного дослідження стали методи перевірки на мультиколінеарність коефіцієнтами Пірсона, декомпозиції адитивних моделей на трендову та циклічну складову, виділення циклічних коливань методом швидкого перетворення Фур'є, екстраполяція побудованих моделей на наступні роки та перевірка якості побудованих моделей за допомогою F-тесту, періодом дослідження обрано щоквартальні дані за 2015-2020 роки. Дослідження емпірично підтверджує та теоретично доводить, що серед досліджуваних фракторів соціально-економічного розвитку велика частина зазнала значних трансформацій, через введення урядом карантинних обмежень. Це обумовлює необхідність проведення інноваційної політики у сфері охорони здоров'я для мінімізації подібних наслідків у майбутньому.

Ключові слова: ряди Фур'є, прогнозування, COVID-19, інновації, декомпозиція часового ряду, охорона здоров'я.

Manuscript received: 30.10 .2020

(C) The author(s) 2020. This article is published with open access at Sumy State University 